\title{
Extension of Cut Carnation Vase Life Using Compost Tea, Putrescine and Plant Extracts
}

\author{
Sanjamveer S. Vehniwal ${ }^{1}$, Raphael Ofoe ${ }^{1}$, Samuel K. Asiedu ${ }^{1}$, Jeff Hoyle ${ }^{1} \&$ Lord Abbey $^{1}$ \\ ${ }^{1}$ Department of Plant, Food, and Environmental Sciences, Faculty of Agriculture, Dalhousie University, 50 \\ Pictou Road, P.O. Box 550, Truro B2N 5E3, Nova Scotia, Canada \\ Correspondence: Lord Abbey, Department of Plant, Food, and Environmental Sciences, Faculty of Agriculture, \\ Dalhousie University, 50 Pictou Road, P.O. Box 550, Truro B2N 5E3, Nova Scotia, Canada. Tel: \\ 1-902-893-6683. E-mail: loab07@gmail.com
}

Received: October 6, 2020 Accepted: December 12, 2020 Online Published: December 18, 2020

doi:10.5539/sar.v10n1p32 URL: https://doi.org/10.5539/sar.v10n1p32

\begin{abstract}
Cut flower vase life can be extended by various natural products, but their efficacy when mixed with compost tea is not reported. A study was performed to determine cut carnation (Dianthus caryophyllus cv. White Sim) vase life in $1 \mathrm{~L}$ of formulations (1) C3.5: $3.5 \%$ compost tea $+15 \mathrm{mg}$ putrescine; (2) R5L10: C3.5 + $5 \mathrm{~mL}$ rosemary (Salvia rosmarinus) $+10 \mathrm{~mL}$ lemon (Citrus limon) extracts; (3) R10L10: C3.5 $+10 \mathrm{~mL}$ rosemary $+10 \mathrm{~mL}$ lemon extracts; (4) R5L20: C3.5 + $5 \mathrm{~mL}$ rosemary $+20 \mathrm{~mL}$ lemon extracts; (5) R10L20: C3.5 + $10 \mathrm{~mL}$ rosemary + $20 \mathrm{~mL}$ lemon extracts; (6) Chrysal: Floral Chrysal Clear (positive control); and (7) Dw: distilled water alone (negative control). The $15 \mathrm{mg}$ putrescine significantly $(\mathrm{P}=0.002)$ reduced compost tea turbidity by $34 \%$. The neutral $\mathrm{pH}$ of $\mathrm{C} 3.5$ and Dw did not change. However, $\mathrm{pH}$ increased by $24 \%$ in Chrysal and reduced by $39 \%$ in R5L10, R10L10 and R5L20 and by 54\% in R10L20 on day 11. TDS and EC were highest in Chrysal from days 1 to 11. Petal discoloration, wilt, shrinkage and neck bend were delayed by C3.5 followed by Chrysal and then R5L10, but were accelerated by the other treatments. In conclusion, the cut carnation cv. White Sim longevity as influenced by variations in the vase solutions was Chrysal (14 days) > C3.5 (12.6 days) > R5L10 (10.7 days) but $\leq 9$ days in the other treatments. These results were confirmed by a 2-D principal component analysis biplot. Future study will investigate microbial interaction.
\end{abstract}

Keywords: cut flower, vase solution, flower longevity

\section{Introduction}

Compost is obtained from the decomposition of organic matter with a remarkably high content of microbial communities, humic and non-humic chemical substances including macro- and micro-nutrients that provide nourishment and protection to plants (Abbey, Annan, Asiedu, Oluwaseun \& Iheshiulo, 2018; Steel et al., 2018). These attributes of compost may also have the potential to extend cut flower freshness and lifespan but not reported. It may be argued that the large number and diverse microbial populations and nutrient density in compost can be a limitation when compost tea is used as cut flower vase solution. For instance, the presence of myriad of microbial cells in compost can cause embolism i.e. blockage of the xylem vessels as observed by Ratnayake, Joyce \& Webb (2010); while salts, basic ions and particulate matter in compost tea can alter the pH, osmotic potential and water balance in cut flowers to affect vase life (Da Silva, 2003; De, Deb, Chhetri \& Rai, 2015). Additionally, suberization due to mechanical wounding and the wound healing process might be impacted by the chemistry of the vase solution. These attributes can reduce the vase life of cut flowers including carnation (Dianthus caryophyllus). Therefore, it was hypothesized that addition of the appropriate natural substances such as essential oils, organic acids, and polyamines to diluted compost tea will extend cut flower freshness and vase life. Moreover, such natural compost tea formulation is low-cost, clean technology, environmentally sound and sustainable.

Essential oils are volatile aromatic compounds obtained by hydro-distillation from plant materials such as leaves, barks, roots, buds, flowers, and seeds (Solgi \& Ghorbanpour, 2014). Many plant-based essential oils such as rosemary (Salvia rosmarinus) and geranium (Pelargonium sp.), and plant-based acidifiers such as citric acid extracted from lime (Citrus aurantiifolia) and orange (Citrus sinensis) have been reported to extend the vase lives of cut flowers (Bazaz \& Tehranifar, 2011; Sun, Cheng, Wu \& Mu, 2019; Vehniwal \& Abbey, 2019). A 
mixture of these plant extracts and compost tea as a vase solution can potentially extend cut flower vase life and replace synthetic chemicals. Another natural product is citric acid which is readily available, cheap and one of the most common organic compounds used to lower $\mathrm{pH}$ and control microbial populations that hastens senescence of cut flowers. More specifically, Sun et al. (2019) reported that $50 \mathrm{mg} / \mathrm{L}$ citric acid extended vase life of sunflower (Helianthus anuus) by five days compared to distilled-water or higher concentrations. In other studies, citric acid extended vase lives of cut carnation (Kazemi \& Ameri, 2012), lisianthus (Eustoma grandiflorum) (Kiamohammadi, 2011) and roses (Rosa $\times$ hybrida) (Jowkar, Kafi, Khalighi \& Hasanzadeh, 2012). Although the extension of cut flower vase life by these natural products were demonstrated, their efficacies when mixed with compost tea have not been reported.

Naturally occurring polyamines such as putrescine, spermidine and spermine are known to interact with a variety of biomolecules and involved in important plant physiological processes. The polycationic nature of putrescine enables it to interact with negatively charged molecules for unique activities such as kosmotropic properties (de la Peña, Sosa-Melgarejo, Ramos \& Mendez, 2000). Kosmotropes like putrescine cause water molecules to favorably interact with other molecules leading to stabilization of macromolecules like proteins. The presence of acidic region and hydrophobic region located between the carbon and nitrogen termini of polyamines provide binding targets for cationic and hydrophobic molecules to cause particle aggregation. The aggregation process of polyamines is ascribed to cationic charge and the number of aliphatic carbon chains between amino groups (Antony et al., 2003). Thus, putrescine can aggregate the organic matter particles dispersed in compost tea to reduce turbidity and the risk of embolism in cut flowers and consequently, enable the required water and material flow up the xylem vessels. Therefore, the present study was performed to determine the extent to which a mixture of compost tea, putrescine and extracts of rosemary and lemon (Citrus limon) as a vase solution can affect the freshness and vase life of cut carnation cv. White Sim.

\section{Materials \& Methods}

\subsection{Location and Materials}

The study was performed under room temperature and relative humidity conditions in the Horticulture Laboratory, Department of Plant, Food, and Environmental Sciences, Faculty of Agriculture, Dalhousie University between spring and summer 2018. Compost Quality Alliance (CQA) tested municipal solid waste (MSW) compost was obtained from Fundy Compost Inc., Brookfield, NS, Canada; lemon and rose extracts purchased from a local retailer (Atlantic Superstore, Truro, NS, Canada); Floral Chrysal Clear (Oasis Flora Products, Kent, Ohio, USA), a synthetic chemical for vase solution, was purchased from Superstore; putrescine (1,4-butanediamine; CAS \#110-60-1; 99\% purity) was purchased from Sigma-Aldrich (Oakville, ON, Canada) and cut carnation cv. White Sim with partially opened flower buds was purchased from Atlantic Superstore.

\subsection{Compost Tea Preparation}

A stock solution of water extract of the MSW compost was prepared by adding $100 \mathrm{~g}$ of 2-mm sieved solid compost at 35\% moisture content to $2 \mathrm{~L}$ of distilled water in an Erlenmeyer flask. The flask was covered with a perforated (2-mm hole) parafilm and the mixture was stirred for $24 \mathrm{hrs}$ at $1100 \mathrm{rpm}$ using a hot plate isotemperature magnetic stirrer (Fisher Scientific, Toronto, ON, Canada). The stirred mixture was then allowed to stand for $24 \mathrm{hrs}$ to settle before filtering using a NALGENE rapid flow filter with disposable bottle top filters lined with a polyethersulfone membrane (Fisher Scientific, Toronto, ON, Canada). Based on a previous study by Abbey et al. (unpublished), a compost tea concentration of $3.5 \%$ was made from the stock and stored in a $4^{\circ} \mathrm{C}$ refrigerator and was used within $72 \mathrm{hrs}$.

\subsection{Compost and Compost Tea Analyses}

Duplicate samples of $300 \mathrm{~g}$ of the solid MSW compost, and $500 \mathrm{~mL}$ each of the stock and the $3.5 \%$ compost tea were sent to the Nova Scotia Department of Agriculture Laboratory Services, Truro, NS for nutrients and microbial analyses. Total nitrogen $(\mathrm{N})$ was determined by the AOAC-990.03 combustion method (AOAC, 2003a) using a LECO-Spec Analyzer (TruSpec ${ }^{\circledR}$ Micro, LECO, MI). The remaining nutrients were determined using the AOAC-968.08 inductively coupled plasma (ICP) spectrometer method (AOAC, 2003b). Total coliform, Salmonella spp. and Escherichia coli were also analyzed using the petri dish method.

\subsection{Putrescine Test}

A test of putrescine alteration of compost tea chemistry was performed and the changes in electric conductivity (EC), salinity, $\mathrm{pH}$ and total dissolved solids (TDS) were determined using a PCS Testr 35 multimeter (EXTECH Instruments, Montreal, QC, Canada). Also, changes in turbidity was determined in Nephelometric Turbidity Unit (NTU) using a T-100 Okaton turbidity meter (EUTECH Instruments Pte Limited, Ayer Rajah, Singapore). The 
treatments were $10,15,20,25$ and $30 \mathrm{mg}$ putrescine/L of $3.5 \%$ compost tea. The mixtures were left on the laboratory bench to react for $48 \mathrm{hrs}$ before analyzing the chemical indices. The experimental design was a completely randomized design with three replications. The $15 \mathrm{mg} / \mathrm{L}$ of $3.5 \%$ compost tea was found to be the optimum rate and was selected for the study (supplementary Table SA1).

Table 1. Naturally formulated vase solution for cut carnation cv. White Sim

\begin{tabular}{ll}
\hline Treatment & Composition of formulation in 1 L vase solution \\
\hline R5L10 & $3.5 \%$ compost tea $+15 \mathrm{mg} / \mathrm{L}$ putrescine $+5 \mathrm{~mL}$ rosemary $+10 \mathrm{~mL}$ lemon \\
R10L10 & $3.5 \%$ compost tea $+15 \mathrm{mg} / \mathrm{L}$ putrescine $+10 \mathrm{~mL}$ rosemary $+10 \mathrm{~mL}$ lemon \\
R5L20 & $3.5 \%$ compost tea $+15 \mathrm{mg} / \mathrm{L}$ putrescine $+5 \mathrm{~mL}$ rosemary $+20 \mathrm{~mL}$ lemon \\
R10L20 & $3.5 \%$ compost tea $+15 \mathrm{mg} / \mathrm{L}$ putrescine $+10 \mathrm{~mL}$ rosemary $+20 \mathrm{~mL}$ lemon \\
C3.5 & $3.5 \%$ compost tea $+15 \mathrm{mg} / \mathrm{L}$ putrescine \\
DW & Distilled water alone \\
Chrysal & Floral Chrysal Clear universal flower food alone \\
\hline
\end{tabular}

$\mathrm{R}$, rosemary; L, lemon; $\mathrm{C}$, compost tea; $\mathrm{DW}$, distilled water. $\mathrm{R}$ and $\mathrm{L}$ were added to $1 \mathrm{~L}$ of $3.5 \%$ compost tea + $15 \mathrm{mg} / \mathrm{L}$ putrescine solution.

\subsection{Formulation of Vase Solution}

One liter $(1 \mathrm{~L})$ of the pre-mixed $3.5 \%$ compost tea and $15 \mathrm{mg}$ putrescine solution was amended with rosemary extract $(5$ or $10 \mathrm{~mL})$ and lemon extract $(10$ or $20 \mathrm{~mL}$ ) (Table 1$)$. The control treatments were $1 \mathrm{~L}$ of Floral Chrysal Clear (positive control) as recommended by the manufacturer and $1 \mathrm{~L}$ of distilled water alone (negative control). The Floral Chrysal Clear is a synthetic chemical preservative that contains $\mathrm{pH}$ regulators, water absorption promoters and flower nutrients.

\subsection{Preparation of Cut Carnation and Treatment}

The leaves on the stem of each cut carnation were removed and a slanted fresh cut was made from the bottom while ensuring equal height and stem diameter for all the cut carnation. That is, each stem was freshly cut under water to prevent air blockage of vessels (i.e. embolism) before the cut stem-end was quickly placed in the individual vase solutions. The remaining young green leaves on each were free of blemishes, damages, and diseases. The vase was a transparent 1-L glass jar containing $500 \mathrm{~mL}$ of each of the vase solution as described in Table 1 . The treatments were arranged in a completely randomized design with five replications with two stem samples of each treatment per replication $(\mathrm{n}=10)$.

\subsection{Data Collection}

\subsubsection{Chemical Analysis}

The turbidity, TDS, EC, salinity, and $\mathrm{pH}$ of the individual vase solutions were recorded on day 1 and every two days up to day 11 . The petals were ground into paste and added to deionized water at a juice/water ratio of 1:2 $(\mathrm{w} / \mathrm{v})$. The total soluble solids $\left({ }^{\circ} \mathrm{Brix}\right)$ content of the petal juice for the individual treatments were analyzed on days 1, 6 and 11 using a RF15 multi-range digital refractometer (EXTECH Instruments, Montreal, QC, Canada). The destructive sampling for the ${ }^{\circ}$ Brix was carried on one of the two stem treatment samples per replication.

\subsubsection{Visual Observation of Cut Carnation Freshness}

The cut carnation was visually inspected and assessed for deterioration every other day and scored on a scale of 1 (extreme) to 5 (no defect) for petal fall, petal discoloration, petal wilt and petal neck bend according to previously defined scoring scale by Dai (1993) and Khan, Shahrin, Taufique, Mehraj \& Jamal Uddin (2015) with some modifications.

The scoring scales were as follows:

(1) Petal discoloration score 1: 90-100\% discoloration; score 1: 60-90\% discoloration; score 2: 30-60\% discoloration; score 3: 10-30\% discoloration; score 4: 1-10\% discoloration; and score 5: field condition, no discoloration.

(2) Petal wilt score 1: extreme wilt; score 2: severe wilt; score 3: moderate wilt; score 4: slight wilt; and score 5: field condition, no signs of wilt.

(3) Petal neck bend score 1: extreme neck bend $>90^{\circ}$; score 2: severe neck bend between $45^{\circ}$ and $90^{\circ}$; score 3 : moderate neck bend between $22.5^{\circ}$ and $45^{\circ}$; score 4 : slight neck bend between $10^{\circ}$ and $22.5^{\circ}$; and score 5: field condition, upright neck and $<10^{\circ}$. 
(4) Total petal fall score 1: $85-100 \%$ of fall; score 1: $60-85 \%$ of fall; score 2: $30-60 \%$ of fall; score 3: $10-30 \%$ of fall; and score 4: $1-10 \%$ of fall; and score 5 : field condition, $<1 \%$ of fall.

\subsubsection{Fresh Weight Loss}

The fresh weight of cut carnations was measured before imposition of the experimental treatment and weighed again every second day up to day 11 . The percentage weight loss (WL) was then calculated as:

$$
W L=\frac{(\text { initial weight-weight on a specific day })}{\text { initial weight }} * 100
$$

\subsubsection{Petal Shrinkage}

Petal shrinkage was determined by changes in petal diameter of fully opened flowers using a 58-6800-4 Mastercraft electronic caliper meter (Mastercraft, Toronto, ON, Canada) every other day from day 1 up to day 11. The percentage shrinkage $(\% \mathrm{~S})$ was calculated for each cut carnation in the individual vase solution with reference to the initial diameter as:

$$
\% S=\frac{\text { (initial diameter-diameter on a specific day) }}{\text { initial diameter }} * 100
$$

\subsubsection{Flower Longevity}

Flower longevity was assessed from the mean score for petal discoloration, petal wilt, petal neck bend and petal fall from day 1 (i.e. mean score of 5) to the time the cut carnations in the individual vase solutions reached 50\% petal deterioration (i.e. mean score of 2.5).

\subsection{Statistical Analysis}

Data collected were subjected to analysis of variance (ANOVA) procedures using a General Linear Model procedure in SAS version 9.4 (SAS Institute Inc., NC, USA) and the treatment means were separated using Fisher's least significant difference (LSD) at $\alpha=0.05$ when the ANOVA indicated significant differences between means at $\mathrm{P} \leq 0.05$. Ordinal data of scores for visually observed data were analyzed using rank-based non-parametric tests of repeated measures but the original data was presented. A principal component analysis biplot was performed to determine the association between the dependent and independent variables using XLSTAT version 19.1 (Addinsoft, NY, USA). Additionally, the correlation amongst the scores for the observed response variables for the cut carnation $\mathrm{cv}$. White Sim and the quality indices for the vase solutions were evaluated using Pearson correlation coefficients in Minitab version 18.3 (Minitab Inc., State College, PA, USA).

\section{Results \& Discussion}

The chemical compositions of the Compost Quality Alliance (CQA) solid phase municipal solid waste (MSW) compost and the stock can be found in supplementary Table SA1 and Table SA2, respectively. The $\mathrm{pH}$ of the stock and the 3.5\% compost tea ( $\mathrm{pH} 7.5)$ did not change despite the distilled water dilution of the solid phase compost ( $\mathrm{pH}$ 7.4). The nutrient composition suggested that the MSW compost tea had adequate nutrients to support cut flower vase life but found to be turbid, which could cause embolism and obstruct the continuous flow of water and materials up the xylem vessels. The preliminary test with putrescine was aimed at reducing the turbidity and stabilize the compost tea. The desired action of the putrescine occurred upon the addition of $15 \mathrm{mg}$ putrescine to the $3.5 \%$ compost tea. The putrescine significantly $(\mathrm{P}=0.002)$ reduced turbidity after 48 hrs by $34 \%$ compared to the control (i.e. 3.5\% compost tea without putrescine) or the highest rate at $30 \mathrm{mg} / \mathrm{L}$ (Table SA3). The action of the putrescine can be attributed to the fact that rapid aggregation at high polyamine concentration formed insoluble small amorphous aggregates (Antony et al., 2003), which might have increased turbidity when more than $15 \mathrm{mg}$ of putrescine was added to the compost tea. However, putrescine did not alter $\mathrm{pH}$, salinity, EC and TDS of the compost tea (Table SA3). Following this finding, we decided to add $15 \mathrm{mg}$ putrescine/L to the $3.5 \%$ compost tea (i.e. treatment C3.5) to reduce turbidity. This was done because particulate matter in the compost increased turbidity of the vase solution, which can cause embolism that will block off water and nutrient flow in the xylem vessels of the cut carnation.

Chrysal was acidic with a $\mathrm{pH}$ of 2.6 while the $\mathrm{pH}$ of $\mathrm{Dw}$ alone and all the $\mathrm{C} 3.5$ formulated vase solutions vary within a narrow range of 7.1 and 7.5 on day 1 . Compost is well known to have good buffering capacity that resist changes in $\mathrm{pH}$, which seemed to be the case from day 1 to day 11 . The $\mathrm{pH}$ of $\mathrm{C} 3.5$ and Dw were relatively stable throughout the 11 days of the experiment. But the $\mathrm{pH}$ of Chrysal increased by $23.7 \%$ on day 11 while the $\mathrm{pH}$ of R5L10, R10L10, R5L20 and R10L200 consistently reduced to acidic levels at 4.1, 4.7, 4.1 and 3.2, respectively on day 11 (Fig. 1A). The treatments with higher citric acid content i.e. R10L20 became more acidic compared to 
R5L10, R10L10 and R5L20. Instability in $\mathrm{pH}$ can be a problem to the cut carnation, and this is explained later by the response variables in this report.

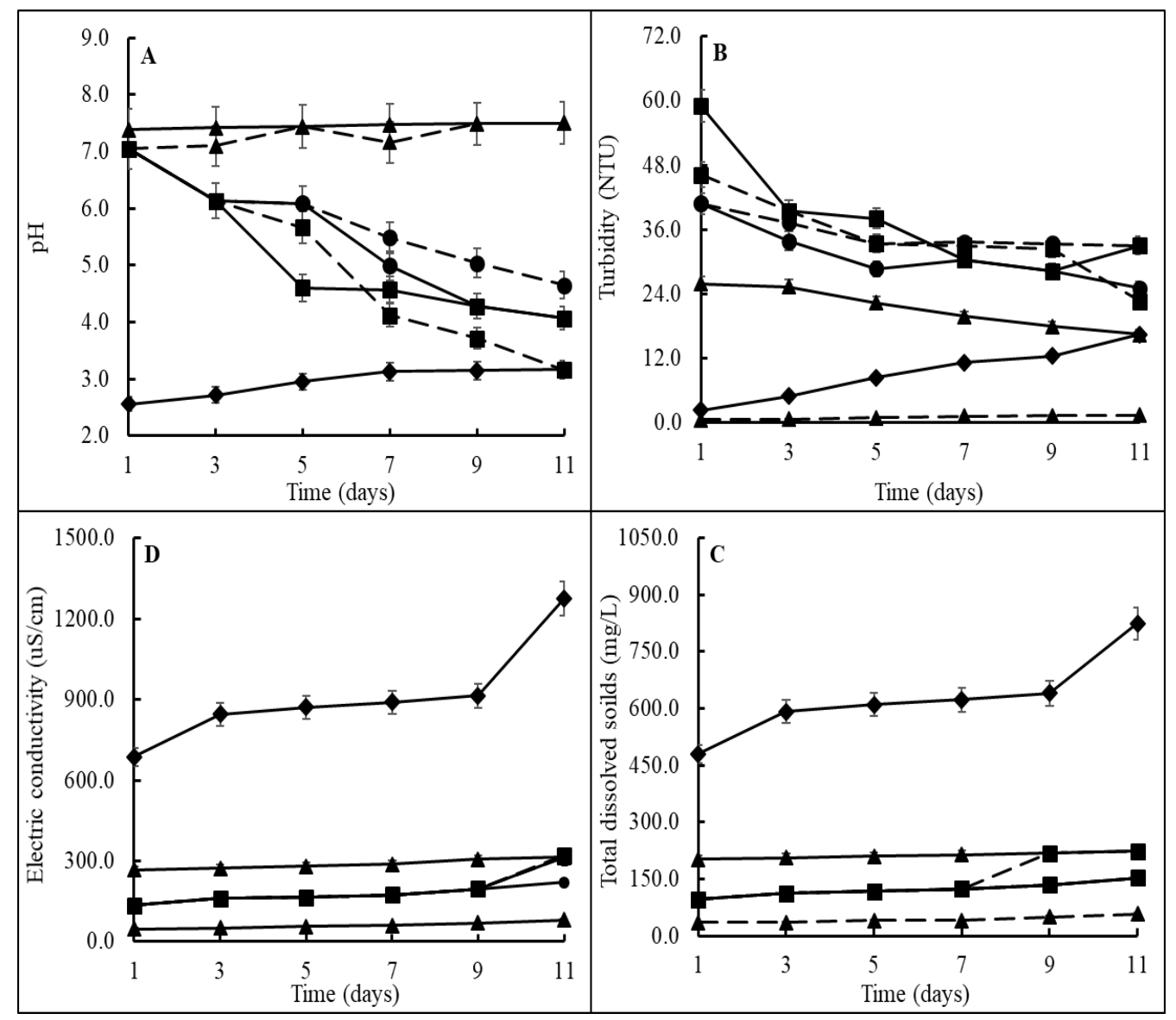

Figure 1. Chemical quality indices for naturally formulated vase solution for cut carnation cv. White Sim

R5L10 (solid line, $\bullet$ ): $3.5 \%$ compost tea $+15 \mathrm{mg} / \mathrm{L}$ putrescine $+5 \mathrm{~mL}$ rosemary $+10 \mathrm{~mL}$ lemon; R10L10 (broken line, $\bullet$ ): $3.5 \%$ compost tea $+15 \mathrm{mg} / \mathrm{L}$ putrescine $+10 \mathrm{~mL}$ rosemary $+10 \mathrm{~mL}$ lemon; R5L20 (solid line, च): $3.5 \%$ compost tea $+15 \mathrm{mg} / \mathrm{L}$ putrescine $+5 \mathrm{~mL}$ rosemary $+20 \mathrm{~mL}$ lemon; $\mathrm{R} 10 \mathrm{~L} 20$ (broken line, $\mathbf{\square}$ ): $3.5 \%$ compost tea $+15 \mathrm{mg} / \mathrm{L}$ putrescine $+10 \mathrm{~mL}$ rosemary $+20 \mathrm{~mL}$ lemon; $\mathrm{C} 3.5$ (solid line, $\boldsymbol{\Delta}$ ): $3.5 \%$ compost tea + $15 \mathrm{mg} / \mathrm{L}$ putrescine; Dw (broken line, $\boldsymbol{\Delta}$ ): distilled water alone; and Chrysal (solid line, $\bullet$ ): Floral Chrysal Clear universal flower food alone.

Turbidity was used to estimate the concentration of particulate matter in the vase solution and varied amongst the different treatments (Fig. 1B). Compared to treatment C3.5 alone, the addition of lemon and rosemary extracts to the $3.5 \%$ compost tea increased the average turbidity by approximately $41 \%$ on day 1 (Fig. 1B). The turbidity values were quite similar for R5L10, R10L10, R5L20 and R10L20 but for the high value for R5L10 on day 1 (Fig 1B). The turbidity of C3.5 declined gently from day 1 to day 11 by which time it declined by $36 \%$. It can be argued that the decline in turbidity in all the compost tea-based formulations were due to precipitation of suspended particulate matter and possibly, a continued activity by the added putrescine as previously explained by de la Peña et al. (2000). The trend in changes in turbidity for Dw and Chrysal were different from the other treatments (Fig. 1B). That is, Dw recorded the least turbidity of 0.69 NTU followed by Chrysal at 2.32 NTU. The turbidity of Dw and Chrysal rose significantly to 1.41 NTU and 16.50 NTU, respectively on day 11. An increase in turbidity of a natural (organic) vase solution can be ascribed to cell leakage from the surface of the cut stem and/or microbial activities (El-Moneim et al., 2018).

Total dissolved solids (TDS) content of the vase solutions may include soluble organic materials and simple and complex chemical substances. TDS content was consistently higher in Chrysal followed by C3.5 from day 1 to 11 while Dw recorded the least (Fig. 1C). All the other vase solutions had similar values of TDS content and as such, their trend lines overlapped in Figure 1C, which was similar for the EC in Figure 1D. We also found that 
the EC strongly but negatively correlated with $\mathrm{pH}(\mathrm{r}=-0.91, \mathrm{P}=0.004$; Table 2$)$. EC is often used to determine the total concentration of ionic substances including estimation of total nutrients in solution. It seemed that as time progressed, soluble solids and ionic substances in the vase solutions increased due to transpiration water loss and water used by the stems for metabolic activities. As a result, the concentration of chemicals in addition to microbial activities and cell leakage were increased. These can explain the significant $(\mathrm{P}<0.05)$ changes in TDS and EC in all the different vase solutions from day 1 to day 11 in the order: C3.5 $(17.3 \%, 10.4 \%)>$ R10L10 $(44.5 \%, 45.5 \%)>\operatorname{R} 5 \operatorname{L} 20(63.7 \%, 59.7 \%)>\operatorname{Dw}(69.8 \%, 66.1 \%)>$ Chrysal $(86.0 \%, 71.6 \%)>$ R5L10 $(104.7 \%$, $100.0 \%)>$ R10L20 $(134.4 \%, 135.7 \%)$.

The petals of the cut carnation cv. White Sim remained intact on the stem in all the vase solutions under the conditions of the present study (data not shown). This suggested that there were adequate nutrients reserve in the plant tissue and the vase solutions to support the petals throughout the 11 days of vase life as similarly reported by Thwala, Wahome, Oseni \& Masariambi (2013). On the contrary, there were significant differences $(\mathrm{P}<0.05)$ in the extent to which petal deterioration occurred amongst the different treatments (Fig. 2A-D). Treatment C3.5 did not record petal discoloration (score of 5.0) up to day 7 while discoloration begun in Chrysal after day 5 (Fig. 2A). However, discoloration increased rapidly in C3.5 from 4.8 on day 9 to 4.0 on day 11. For Chrysal, discoloration slightly increased from a score of 5 on day 5 to 4.4 on days 9 and 11 . In contrast, there was a steady increase in discoloration in R5L10 from a score of 5.0 on day 5 to a score of 3.3 (moderate) on days 9 and 11.

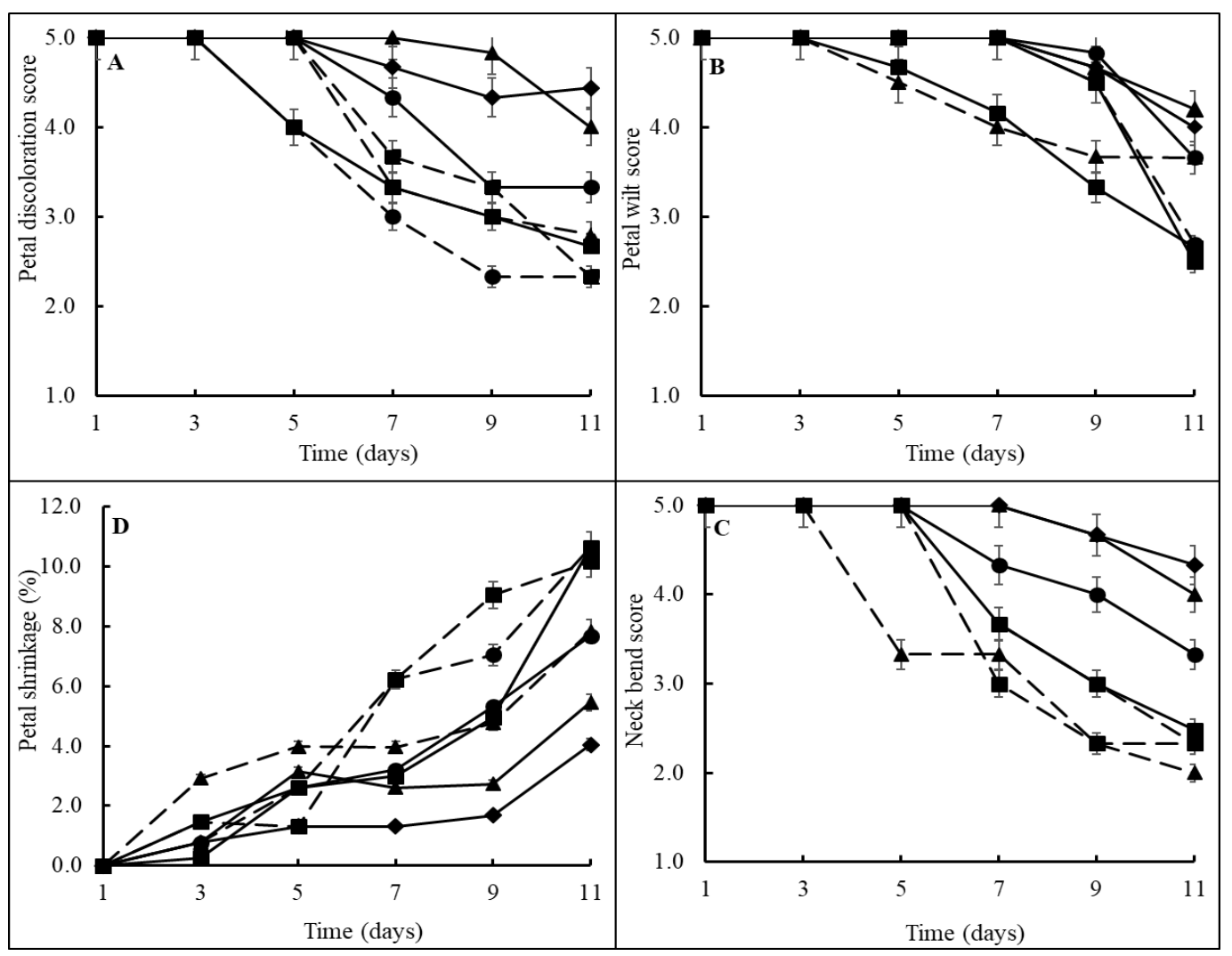

Figure 2. Response of cut carnation cv. White Sim to naturally formulated vase solution using a scoring scale from 1 (extreme defects) to 5 (no defect)

R5L10 (solid line, $\bullet$ ): $3.5 \%$ compost tea $+15 \mathrm{mg} / \mathrm{L}$ putrescine $+5 \mathrm{~mL}$ rosemary $+10 \mathrm{~mL}$ lemon; $\mathrm{R} 10 \mathrm{~L} 10$ (broken line, $\bullet$ ): $3.5 \%$ compost tea $+15 \mathrm{mg} / \mathrm{L}$ putrescine $+10 \mathrm{~mL}$ rosemary $+10 \mathrm{~mL}$ lemon; R5L20 (solid line, घ): $3.5 \%$ compost tea $+15 \mathrm{mg} / \mathrm{L}$ putrescine $+5 \mathrm{~mL}$ rosemary $+20 \mathrm{~mL}$ lemon; R10L20 (broken line, $\mathbf{\square}): 3.5 \%$ compost tea $+15 \mathrm{mg} / \mathrm{L}$ putrescine $+10 \mathrm{~mL}$ rosemary $+20 \mathrm{~mL}$ lemon; $\mathrm{C} 3.5$ (solid line, $\boldsymbol{\Delta}$ ): $3.5 \%$ compost tea + $15 \mathrm{mg} / \mathrm{L}$ putrescine; Dw (broken line, $\boldsymbol{\Delta}$ ): distilled water alone; and Chrysal (solid line, $\bullet$ ): Floral Chrysal Clear universal flower food alone.

Discoloration of the cut carnations was fastest in R10L10 and R5L20 followed by Dw and R10L20 from days 1 to 11. On day 11, discoloration was severe in R10L10 and R10L20 with the same score of 2.3. The R5L20 and Dw appeared to have increased discoloration in a linear fashion until day 9 when the effect of the latter on petal 
color remained constant at a score of 3.3 up to day 11 while discoloration continued in the former to a score of 2.3 on day 11. The extension of vase life of the carnations is good for customer satisfaction and marketability.

There were no signs of petal wilt on the cut carnation in treatments C3.5, Chrysal, R5L10, R10L10 and R10L20 until after day 7 when wilting became visible (Fig. 2B). Petal wilt was slowed down in C3.5 and Chrysal followed by R5L10. Petal wilt was accelerated by R10L10 and R10L20 after day 9 at a score of 4.7 to day 11 at a score of 2.5. Petal wilt begun from day 3 in Dw and flattened after day 9 but steadily wilted in a linear fashion in R5L20 up to day 11. Similarly, the score for neck bend was delayed mostly by treatments C3.5 and Chrysal until day 7 followed by R5L10, R5L20, R10L10 and R10L20 until day 5 and the least by Dw until day 3 (Fig. 2C). Once initiated, neck bend proceeded rapidly and can be categorized into three groups i.e. slight (mean score of 4.2) in C3.5 and Chrysal, moderate (score of 3.3) in R5L10 and severe (mean score of 2.3) in R5L20, R10L10, R10L20 and Dw. In-rolling, wilting, discoloration, and margin necrosis of petals are typical symptoms of flower senescence induced by ethylene in carnation (Satoh, Shibuya, Waki \& Kosugi, 2005). Although ethylene evolution was not monitored, we believe it played a critical role in the wilting of the petals as influenced by the different vase solutions.

Percentage petal shrinkage of the cut carnation cv. White Sim was increased gradually by all the treatments from day 1 (Fig. 2D). Comparatively, petal shrinkage highly increased in Dw until day 5 before flattening for three days and then rose again after day 9. After day 5, petal shrinkage was steeply increased by R10L10 and R10L20 up to day 11. For R5L10 and R5L20, petal shrinkage increased after day 7. Comparatively, petal shrinkage was slightly increased by C3.5 and Chrysal after day 3 and remained low until day 9 when it rose from $2.7 \%$ to $5.5 \%$ for C3.5 and from $1.7 \%$ to $4.0 \%$ for Chrysal on day 11. Overall, petal shrinkage was least in the Chrysal followed by C3.5. Dw and R5L10 caused moderate petal shrinkage of 7.9\% and the highest shrinkage of $10.2 \%$ was caused by R10L10, R10L20 and R5L20. Cut flower petal wilt can be ascribed to depleted plant food and inability of the plant to draw up water. This can eventually lead to flaccidity of cells and increased neck bend, petal shrinkage and subsequent color change and ultimate manifestation of flower death (Thwala et al., 2013). Also, water balance in cut flower is a major factor determining longevity (Da Silva, 2003) and can be affected by water-deficit stress imposed when water uptake lags behind transpiration.

Total soluble solids (TSS) content of cut carnation in the three best performing vase solutions i.e. C3.5, Chrysal and R5L10 with Dw as the control were tested for additional information on tissue assimilate depletion effect on flower longevity. We found that petal TSS contents in all the vase solutions tested were consistently reduced from day 1 to day 11 (Fig. 3). By day 6, the petal TSS content was reduced by approximately $1.7 \%, 15 \%, 15 \%$ and 45\% in Chrysal, Dw, R5L10 and C3.5, respectively.

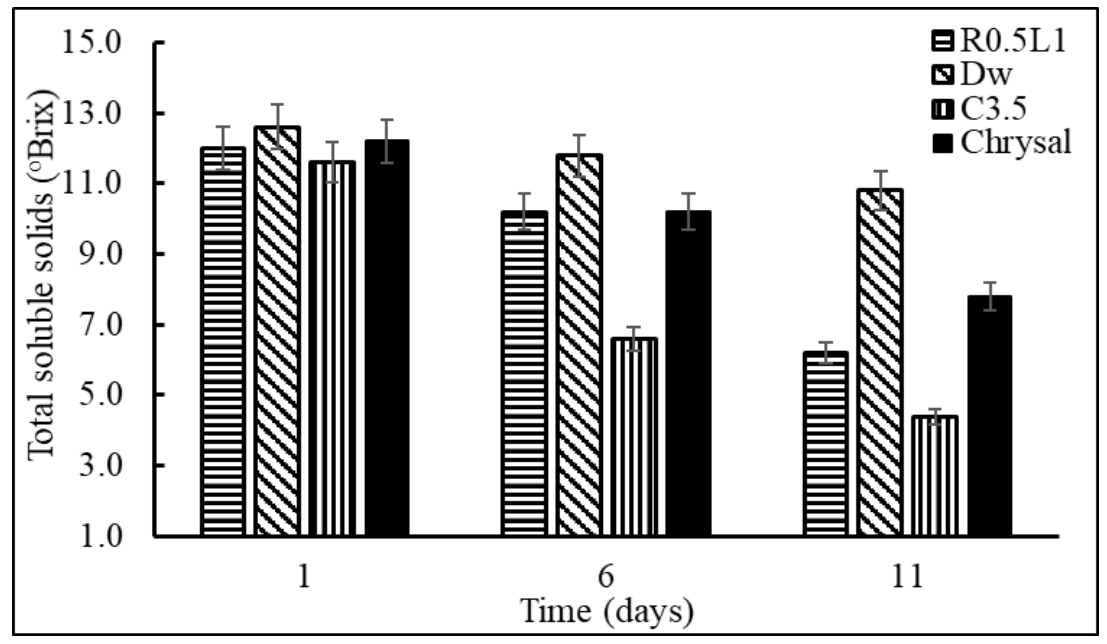

Figure 3. Total soluble solids content of cut carnation cv. White Sim petals as affected by naturally formulated vase solution

R5L10: $3.5 \%$ compost tea $+15 \mathrm{mg} / \mathrm{L}$ putrescine $+5 \mathrm{~mL}$ rosemary $+10 \mathrm{~mL}$ lemon; $\mathrm{C} 3.5: 3.5 \%$ compost tea +15 $\mathrm{mg} / \mathrm{L}$ putrescine; Dw: distilled water alone; and Chrysal: Floral Chrysal Clear universal flower food alone.

However, the trend in the percentage reduction of petal TSS contents changed between day 6 and day 11 to Dw $(39.2 \%)>\mathrm{C} 3.5(33.3 \%)>\mathrm{R} 5 \mathrm{~L} 10(23.5 \%)>$ Chrysal $(8.5 \%)$. It appeared the humic and non-humic substances in 
the compost tea formulations i.e. R5L10 and C3.5 enabled the cut carnations to continue with carbohydrates catabolism for growth and maintenance respiration with a resultant reduction in petal TSS content. This finding must be investigated further. In contrast, Chrysal is a synthetic chemical preservative designed for cut flowers and contained $\mathrm{pH}$ regulators, water absorption promoters and flower nutrients. Therefore, the chemical composition of Chrysal could explain its low impact on petal TSS content as confirmed by the strong negative association $(\mathrm{r}=-0.85, \mathrm{P}=0.015)$ between vase solution $\mathrm{pH}$ versus petal TSS content (Table 2$)$. The Dw, on the other hand, reduced petal TSS content the most by 39.2\% between day 6 and day 11. Dw was the blank and contain negligible amounts of supporting nutrients. It can be suggested that the cut carnation in the Dw depended solely on the plant tissue nutrient reserves, which were rapidly depleted as a result. Although the association between petal TSS content and vase solution EC was non-significant, it was moderate and positive $(\mathrm{r}=0.63, \mathrm{P}=$ 0.133; Table 2). Previous report explained that a reduction in soluble carbohydrates reduction in soluble carbohydrates. as determined by TSS content can trigger a climacteric-like production of ethylene leading to the hastening of petal senescence and vice versa (Ichimura \& Suto, 1999; Pun et al., 2016).

Table 2. Pearson correlation coefficients ( $\mathrm{r}$ ) and their significance at $\mathrm{P} \leq 0.05$ amongst naturally formulated vase solution $\mathrm{pH}$ and electric conductivity (EC) and cut carnation cv. White Sim petal weight loss, shrinkage, total soluble solids (TSS) and longevity

\begin{tabular}{llllll}
\hline & EC & Weight loss & Petal shrinkage & TSS & Petal longevity \\
\hline pH & $\mathrm{r}=-0.91$ & $\mathrm{r}=0.71$ & $\mathrm{r}=0.46$ & $\mathrm{r}=-0.85$ & $\mathrm{r}=-0.58$ \\
& $\mathrm{P}=0.004$ & $\mathrm{P}=0.072$ & $\mathrm{P}=0.302$ & $\mathrm{P}=0.015$ & $\mathrm{P}=0.171$ \\
EC & - & $\mathrm{r}=-0.91$ & $\mathrm{r}=-0.68$ & $\mathrm{r}=0.63$ & $\mathrm{r}=0.82$ \\
& & $\mathrm{P}=0.005$ & $\mathrm{P}=0.095$ & $\mathrm{P}=0.133$ & $\mathrm{P}=0.025$ \\
Weight loss & - & - & $\mathrm{r}=0.81$ & $\mathrm{r}=-0.40$ & $\mathrm{r}=-0.96$ \\
& & & $\mathrm{P}=0.028$ & $\mathrm{P}=0.380$ & $\mathrm{P}=0.001$ \\
Petal shrinkage & - & - & - & $\mathrm{r}=0.02$ & $\mathrm{r}=-0.92$ \\
TSS & - & - & - & $\mathrm{P}=0.97$ & $\mathrm{P}=0.004$ \\
& & & & - & $\mathrm{r}=0.20$ \\
\end{tabular}

This finding agreed with the current observed variation in cut carnation percentage fresh weight loss and petal longevity (Figure 4A-B).

Reduction in cut carnation petal percentage fresh weight was strongly and positively correlated $(\mathrm{r}=0.81, \mathrm{P}=$ 0.028) with petal shrinkage (Table 2). Separation between treatments with respect to percentage reduction in petal fresh weight became obvious before day 3 (Fig. 4A). In general, cut carnation weight loss increased gradually until it reached a phase of steep rise depending on the treatment. The highest reducer of percentage petal fresh weight was Dw followed by those vase solutions containing high amount of lemon extract i.e. R5L20 and R10L20. The percentage petal weight reduction was similar for Dw and R5L20 from day 1 until after day 7 when it slowed down in the latter. All the other vase solutions, i.e. Dw > R5L20 > R10L20 > R10L10, recorded a high percentage weight loss ranging from 17.9 to $26.8 \%$. Other studies reported a significantly high cut flower petal weight loss in tap or distilled water as compared to other preservative solutions (Penniston, Nakada, Holmes \& Assimos, 2008; Mehraj, Ona, Taufique \& Jamal Uddin, 2013). 


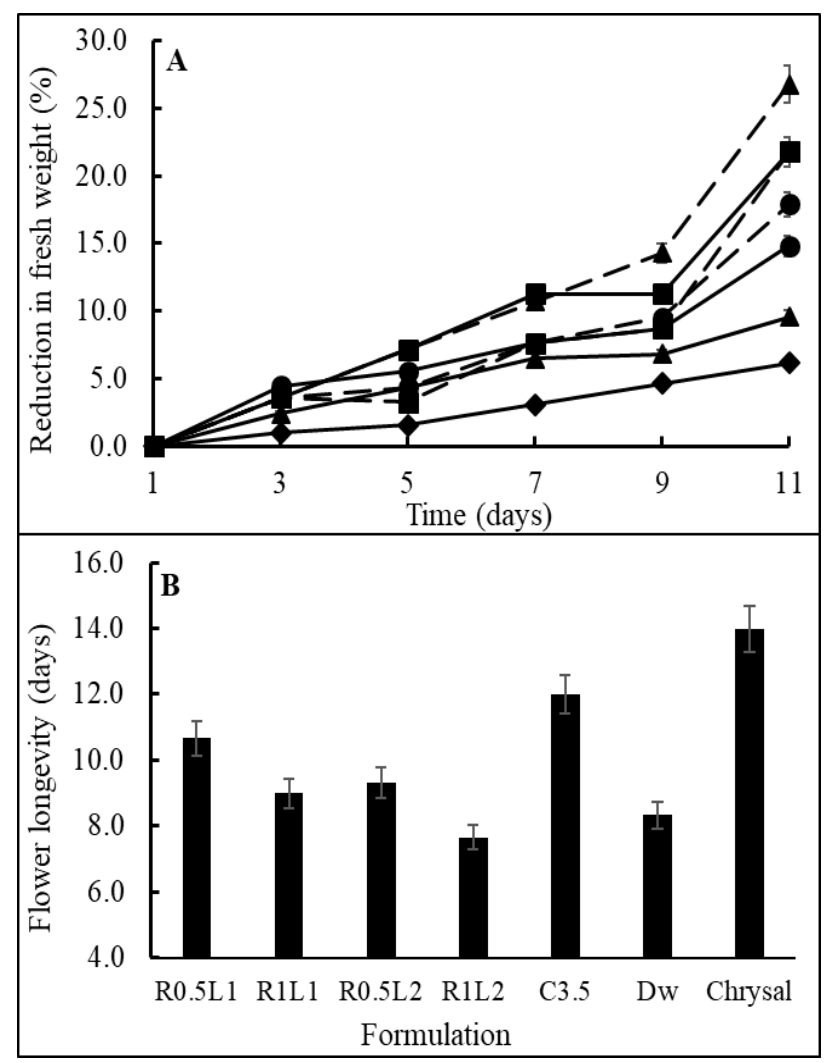

Figure 4. Reduction in fresh weight (panel A) and time to 50\% petal deterioration (panel (B) of cut carnation cv. White Sim treated with different naturally formulated vase solution

R5L10 (solid line, $\bullet$ ): $3.5 \%$ compost tea $+15 \mathrm{mg} / \mathrm{L}$ putrescine $+5 \mathrm{~mL}$ rosemary $+10 \mathrm{~mL}$ lemon; R10L10 (broken line, $\bullet$ ): $3.5 \%$ compost tea $+15 \mathrm{mg} / \mathrm{L}$ putrescine $+10 \mathrm{~mL}$ rosemary $+10 \mathrm{~mL}$ lemon; R5L20 (solid line, 口): $3.5 \%$ compost tea $+15 \mathrm{mg} / \mathrm{L}$ putrescine $+5 \mathrm{~mL}$ rosemary $+20 \mathrm{~mL}$ lemon; R10L20 (broken line, $\mathbf{\square}$ ): $3.5 \%$ compost tea $+15 \mathrm{mg} / \mathrm{L}$ putrescine $+10 \mathrm{~mL}$ rosemary $+20 \mathrm{~mL}$ lemon; $\mathrm{C} 3.5$ (solid line, $\mathbf{\Delta}$ ): $3.5 \%$ compost tea + $15 \mathrm{mg} / \mathrm{L}$ putrescine; Dw (broken line, $\boldsymbol{\Lambda}$ ): distilled water alone; and Chrysal (solid line, $\bullet$ ): Floral Chrysal Clear universal flower food alone.

The reason being nutrients availability in vase solution is critical for cut flower survival as confirmed by the strong negative correlation $(\mathrm{r}=-0.91, \mathrm{P}=0.005)$ between the percentage petal weight loss versus vase solution $\mathrm{EC}$; but non-significant and moderately positive association with vase solution $\mathrm{pH}(\mathrm{r}=0.71, \mathrm{P}=0.072$; Table 2). Percentage weight loss was comparatively lowest in Chrysal (6.2\%) followed by C3.5 (9.6\%) and then R5L10 $(14.8 \%)$ at each time point from day 1 to day 11. It could therefore be surmised that the vase solutions, particularly C3.5 and Chrysal were the most effective and played roles as antimicrobial agents and inhibited the growth of microorganisms and consequently, prevented the occlusion of xylem vessels. Significant differences $(\mathrm{P}<0.05)$ were observed for flower longevity in the different preservative solutions (Fig. 4B). The longest cut carnation cv. White Sim vase life was recorded in Chrysal followed by C3.5 and then R5L10.

The trend for the cut carnation longevity as influenced by the variations in vase solution was Chrysal (14 days) > C3.5 (12.6 days) $>$ R5L10 (10.7 days) $>$ R10L10 = R5L20 $(9.1$ days $)>\operatorname{Dw}(8.3$ days $)>\operatorname{R} 10 \mathrm{~L} 20$ (7.7 days). Usually, cell sap oozes out of wounded stem-ends leading to multiplication of microbes in vase water, which can clog xylem vessels (Thanusha, 2017). This could explain the hastened senescence of the cut carnation in Dw. Overall, an increase in longevity of the cut carnation was strongly and positively associated with an increase in vase solution $\mathrm{EC}(\mathrm{r}=0.82, \mathrm{P}=0.025)$, but strongly and negatively associated with percentage petal weight loss $(\mathrm{r}=-0.96, \mathrm{P}=0.001)$ and petal shrinkage $(\mathrm{r}=-0.92, \mathrm{P}=0.004$; Table 2$)$.

The two-dimension (2-D) principal component analysis (PCA) biplot (Figure 5) summarizes the relationship between the various independent and response variables. The 2-D PCA explained a total of $87 \%$ of the total variations in the dataset. It showed that variables that are clustered together or have narrow angles $\left(<90^{\circ}\right)$ signify positive relationships, those that are separated or at obtuse $\left(>90^{\circ}\right)$ angles signify negative relationship and those 
that are at right-angles $\left(=90^{\circ}\right)$ signify no relationship. There was a clear separation between C3.5, Chrysal and the other vase solutions.

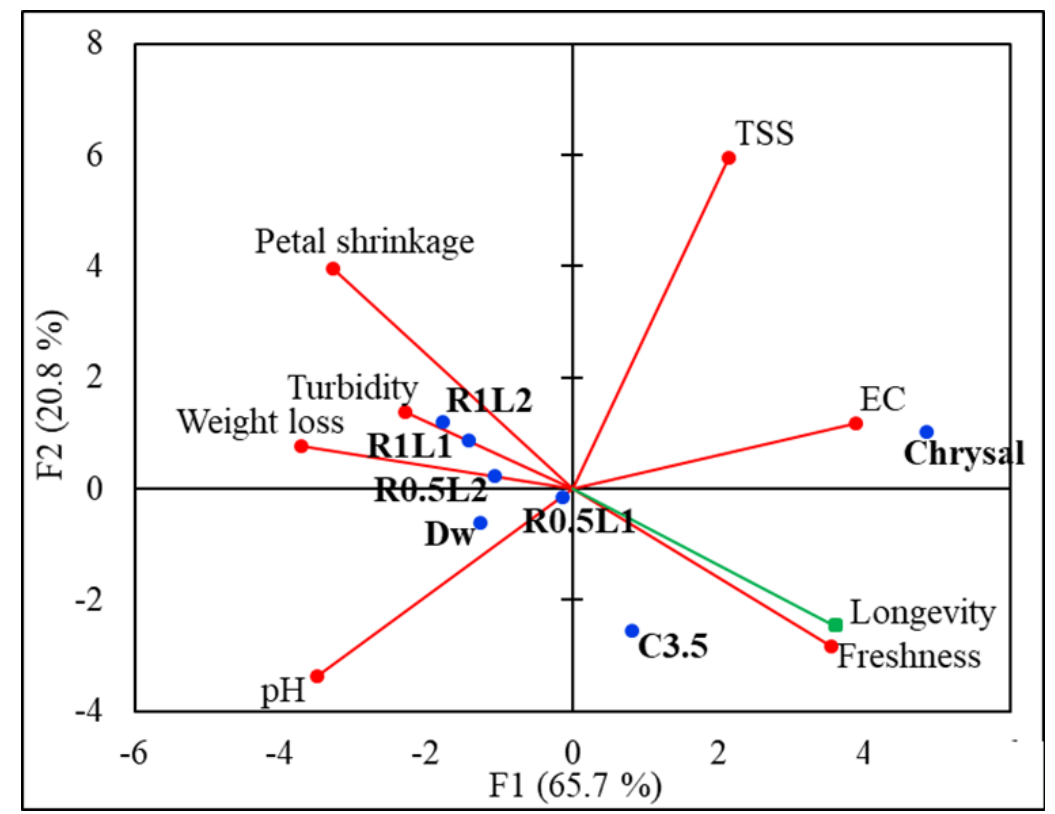

Figure 5. A two-dimensional principal component analysis biplot showing relationships amongst different naturally formulated vase solutions versus chemical quality indices and cut carnation cv. White Sim vase quality components

R5L10: $3.5 \%$ compost tea $+15 \mathrm{mg} / \mathrm{L}$ putrescine $+5 \mathrm{~mL}$ rosemary $+10 \mathrm{~mL}$ lemon; $\mathrm{R} 10 \mathrm{~L} 10: 3.5 \%$ compost tea + $15 \mathrm{mg} / \mathrm{L}$ putrescine $+10 \mathrm{~mL}$ rosemary $+10 \mathrm{~mL}$ lemon; R5L20: $3.5 \%$ compost tea $+15 \mathrm{mg} / \mathrm{L}$ putrescine $+5 \mathrm{~mL}$ rosemary $+20 \mathrm{~mL}$ lemon; $\mathrm{R} 10 \mathrm{~L} 20: 3.5 \%$ compost tea $+15 \mathrm{mg} / \mathrm{L}$ putrescine $+10 \mathrm{~mL}$ rosemary $+20 \mathrm{~mL}$ lemon; C3.5: $3.5 \%$ compost tea $+15 \mathrm{mg} / \mathrm{L}$ putrescine; Dw: distilled water alone; and Chrysal: Floral Chrysal Clear universal flower food alone. Total soluble solids (TSS).

Therefore, the PCA biplot suggested that Chrysal had the highest EC and the least $\mathrm{pH}$ and turbidity, but increased petal TSS content and reduced both petal shrinkage and petal weight loss while C3.5 had higher EC and $\mathrm{pH}$ but low turbidity and reduced petal TSS content, petal shrinkage and petal weight loss. Consequently, both Chrysal in quadrant 1 and C3.5 in quadrant 2 enhanced cut carnation freshness and longevity. R5L20, R10L10, R10L20 and Dw were grouped around quadrants 3 and 4 due to their similarity and were slightly separated from R5L10 which is located in the center. These group of vase solutions had higher pH and turbidity and increased cut carnation petal shrinkage and petal weight loss. Consequently, their location on the 2-D PCA biplot suggested their reduced effects on cut carnation freshness and longevity as compared to Chrysal and C3.5. The difference between the effects of C3.5 and Chrysal did not appear to be significant considering their relative distance from the locations of freshness and longevity in quadrant 2. Compost contains humic substances (i.e. humic acids, fulvic acids and humin), non-humic substances (e.gs, organic acids, amino acids, nucleic acids, mineral nutrients, carbohydrates, fatty acids, plant growth regulators, e.t.c.) and beneficial microbiome (Pena-Mendez et al., 2005; Hayes et al., 2017; Abbey et al., 2018). As a result, compost alters many fundamental plant structural, biochemical and physiological functions. Therefore, observed extension of cut carnation cv. White Sim longevity and freshness by the compost tea (i.e. C3.5) treatment can be ascribed to the inherent properties of compost and the availability of plant growth factors. It is also worth noting that the effect of the putrescine alone was not evaluated in this study but will be investigated in a future study.

\section{Conclusion}

Synthetic chemical preservatives contain sugars, acidifiers, water uptake enhancers and biocides that extend vase lives of different species of cut flowers. But these synthetic chemicals are expensive and not safe to the environment and health of living forms. The proposed alternative to synthetic chemicals is a disruptive natural formulation that is relatively low cost, efficacious, and safe to humans and the environment. The results of our present study demonstrated the extension of cut carnation cv. White Sim freshness and longevity using 3.5\% compost tea with added putrescine $(15 \mathrm{mg} / \mathrm{L})$, which was comparable to Chrysal, a synthetic chemical 
preservative. The other close alternative is the use of a vase solution containing 3.5\% compost tea amended with putrescine $(15 \mathrm{mg} / \mathrm{L})$ and extracts of rosemary $(0.5 \mathrm{~mL})$ and lemon $(1 \mathrm{~mL})$. The combined additives contain humic and non-humic substances including plant nutrients, biostimulants, antimicrobial agents, $\mathrm{pH}$ buffer and turbidity reducer. Thus, these additives modulated vase solution chemistry and provided nourishment and vitality to the cut carnation that contributed to the extension of vase life. Water alone does not sustain cut flower. It is also important to test these natural formulations and the putrescine alone on different species of cut flower and to investigate the mechanism of action.

\section{Funding}

This study was funded by Divert Nova Scotia (Award \#RRFB 16-01) of which the authors are most grateful.

\section{Acknowledgement}

This work was supported by Divert Nova Scotia, Truro, NS [grant number RRFB 16-01, 2016]; and Fundy Compost Inc., Brookfield, NS who donated the municipal solid waste compost.

\section{References}

Abbey, L., Annan, N., Asiedu, S. K., Oluwaseun, E. E., \& Iheshiulo, E. M-A. (2018). Amino acids, mineral nutrients and efficacy of vermicompost and seafood and municipal solid wastes composts. International Journal of Agrononomy, 8, 1-6. https://doi.org/10.1155/2018/6419467

Antony, T., Hoyer, W., Cherny, D., Heim, G., Jovin, T. M., \& Subramaniam, V. (2003). Cellular polyamines promote the aggregation of $\alpha$-synuclein. Journal of Biological Chemistry, 278(5), 3235-3240. https://doi.org/10.1074/jbc.M208249200

AOAC. (2003a). Protein (crude) in animal feed: combustion method, AOAC official method 990.03. Official methods of analysis (17th ed.). Association of Official Analytical Chemists, Gaithersburg, MD.

AOAC. (2003b). Metals and other elements in plants and pet foods: inductively coupled plasma spectroscopic method, AOAC official method 968.08. Official methods of analysis (17th ed.). Association of Official Analytical Chemists, Gaithersburg, MD.

Bazaz, A. M., \& Tehranifar, A. (2011). Effect of ethanol, methanol and essential oils as novel agents to improve vase-life of Alstroemeria flowers. Journal of Biology and Environment Science, 5(14): 41-46.

Dai, J. (1993). Postharvest leaf blackening in Protea neriifolia R. Br. Doctoral dissertation, University of Hawaii. Retrieved from http://hdl.handle.net/10125/9903

Da Silva, J. A. T. (2003). The cut flower: postharvest considerations. Journal of Biological Sciences, 3(4), 406-442. https://doi.org/10.3923/jbs.2003.406.442

de la Peña, N. C., Sosa-Melgarejo, J. A., Ramos, R. R., \& Méndez, J. D. (2000). Inhibition of platelet aggregation by putrescine, spermidine, and spermine in hypercholesterolemic rabbits. Archives of Medical Research, 31(6), 546-550. https://doi.org/10.1016/S0188-4409(00)00238-1

De, L.C., Deb, P., Chhetri, G., \& Rai, D. (2015). Pre- and Post-harvest physiology of Cymbidium Orchids. International Journal of Horticulture, 5(6), 1-5. https://doi.org/10.5376/ijh.2015.05.0006

El-Moneim, A. A., Abdel-Fattah, G., \& Khenizy, S. (2018). Effect of natural extracts on vase life of gypsophila cut flowers. Scientific Journal of Flowers and Ornamental Plants, 1(1), 1-16.

Ichimura, K., \& Suto, K. (1999). Effects of the time of sucrose treatment on vase life, soluble carbohydrate concentrations and ethylene production in cut sweet pea flowers. Plant Growth Regulation, 28(2), 117-122. https://doi.org/10.1023/A:1006288031997

Jowkar, M. M., Kafi, M., Khalighi, A., \& Hasanzadeh. (2012). Evaluation of aluminum sulfate as vase solution biocide on postharvest microbial and physiological properties of 'Cherry Brandy' rose. Annals of Biological Research, 3(2), 1132-1144.

Kazemi, M., \& Ameri, A. (2012). Response of vase-life carnation cut flower to salicylic acid, silver nanoparticles, glutamine and essential oil. Asian Journal of Animal Science, 6(3), 122-131. https://doi.org/10.3923/ajas.2012.122.131

Khan, P., Shahrin, S., Taufique, T., Mehraj, H., \& Jamal, U. A. F. M. (2015). Prolonging vase life of cut rose (Rosa hybrida L. cv. Red Pearl) through chemical preservatives. Journal of Bioscience and Agriculture Research, 5(1), 10-15. https://doi.org/10.18801/jbar.050115.49

Kiamohammadi, M. (2011). The effects of different floral preservative solutions on vase life of lisianthus cut 
flowers. Journal of Ornamental and Horticultural Plants, 1(2), 115-122.

Mehraj, H., Ona, A. F., Taufique, T., Mutahera, S., \& Jamal, U. A. F. M. (2013). Vase life quality improvement of white snowball using vase life extending solutions. Bangladesh Research Publications, 8(3), 191-194. Retrieved from https://ssrn.com/abstract=3570461

Penniston, K. L., Nakada, S. Y., Holmes, R. P., \& Assimos, D. G. (2008). Quantitative assessment of citric acid in lemon juice, lime juice, and commercially-available fruit juice products. Journal of Endourology, 22(3), 567-570. https://doi.org/10.1089/end.2007.0304

Pun, U. K., Yamada, T., Azuma, M., Tanase, K., Yoshioka, S., Shimizu-Yumoto, H., Satoh, S., \& Ichimura, K. (2016). Effect of sucrose on sensitivity to ethylene and enzyme activities and gene expression involved in ethylene biosynthesis in cut carnations. Postharvest Biology and Technology, 121, 151-158. https://doi.org/10.1016/j.postharvbio.2016.08.001

Ratnayake, K., Joyce, D., \& Webb, R. (2010). Microscopy studies of xylem occlusions in cut Acacia holosericea foliage stems. In the 21st Australian Conference on Microscopy and Microanalysis. Australian Microscopy and Microanalysis Society. p. 221-221.

Satoh, S., Shibuya, K., Waki, K., \& Kosugi, Y. (2005). Mechanism of senescence in carnation flowers. ISHS Proc. VIIIth Postharvest Physiology of Ornamentals. Acta Horticulturae, 669, 191-195. https://doi.org/10.17660/ActaHortic.2005.669.24

Solgi, M., \& Ghorbanpour, M. (2014). Application of essential oils and their biological effects on extending the shelf-life and quality of horticultural crops. Trakia Journal of Sciences, 2, 198-210. Retrieved from http://www.uni-sz.bg

Sun, T. Z., Cheng, S. S., Wu, W. J., \& Mu, H. (2019). Effect of citric acid on freshness preservation in cut sunflowers (Helianthus annuus L.). Horticultural International Journal, 3(4), 201-204. https://doi.org/10.15406/hij.2019.03.00131

Steel, H., Moens, T., Vandecasteele, B., Hendrickx, F., De Neve, S., Neher, D. A., \& Bert, W. (2018). Factors influencing the nematode community during composting and nematode-based criteria for compost maturity. Ecological Indicators, 85, 409-421. https://doi.org/10.1016/j.ecolind.2017.10.039

Thanusha, K. (2017). Effect of botanical floral preservatives on postharvest quality of gerbera (Gerbera jamesonii L.) cut flower. Doctoral dissertation, Dr. Ysr horticultural university. Retrieved from http://krishikosh.egranth.ac.in/handle/1/5810036433

Thwala, M., Wahome, K., Oseni, O., \& Masariambi, T. (2013). Effects of floral preservatives on the vase life of Orchid (Epidendrum radicans L.) cut flowers. Horticultural Science and Ornamental Plants, 5, 22-29.

Vehniwal, S. S., \& Abbey, L. (2019). Cut flower vase life - influential factors, metabolism and organic formulation. Horticultural International Journal, 3(6), 275-281. https://doi.org/10.15406/hij.2019.03.00142 


\section{Appendix A}

Table A1. Chemical properties and most probable number (MPN) of microorganisms in Compost Quality Alliance tested solid phase municipal solid waste compost

\begin{tabular}{|c|c|c|}
\hline Compost Parameters & Unit & Value \\
\hline $\mathrm{pH}$ & & 7.7 \\
\hline Cation exchange capacity & Meq per100 g & 48.6 \\
\hline Organic matter & $\%$ & 25.21 \\
\hline Total nitrogen & $\%$ & 1.72 \\
\hline Carbon:nitrogen $(\mathrm{C}: \mathrm{N})$ ratio & & $9: 1$ \\
\hline Escherichia coli & $\mathrm{MPN} \mathrm{g}^{-1}$ dry & 6 \\
\hline Fecal coliform & $\mathrm{MPN} \mathrm{g}^{-1}$ dry & 6 \\
\hline Salmonella spp. & P-A per $25 \mathrm{~g}$ & Negative \\
\hline Total argon & $\mathrm{mgkg}^{-1}$ & 7.14 \\
\hline Total cobalt & $\mathrm{mgkg}^{-1}$ & 7.10 \\
\hline Total chromium & $\mathrm{mgkg}^{-1}$ & 17.75 \\
\hline Total copper & $\mathrm{mgkg}^{-1}$ & 50.50 \\
\hline Total mercury & $\mathrm{mgkg}^{-1}$ & 0.11 \\
\hline Total molybdenum & $\mathrm{mgkg}^{-1}$ & 1.3 \\
\hline Total nickel & $\mathrm{mgkg}^{-1}$ & 14.77 \\
\hline Total lead & $\mathrm{mgkg}^{-1}$ & 24.25 \\
\hline Total phosphorus & $\mathrm{mgkg}^{-1}$ & 681 \\
\hline Total potassium & $\mathrm{mgkg}^{-1}$ & 2252 \\
\hline Total magnesium & $\mathrm{mgkg}^{-1}$ & 839 \\
\hline Total calcium & $\mathrm{mgkg}^{-1}$ & 6676 \\
\hline Total sulphur & $\mathrm{mgkg}^{-1}$ & 125 \\
\hline Total zinc & $\mathrm{mgkg}^{-1}$ & 49.5 \\
\hline Total manganese & $\mathrm{mgkg}^{-1}$ & 68 \\
\hline Total iron & $\mathrm{mgkg}^{-1}$ & 339 \\
\hline Total sodium & $\mathrm{mgkg}^{-1}$ & 592 \\
\hline
\end{tabular}

Table A2. Chemical properties of municipal solid waste compost tea stock solution used for the preparation of the $3.5 \%$ compost tea concentrations

\begin{tabular}{lll}
\hline Parameters & Unit & Value \\
\hline $\mathrm{pH}$ & & 7.43 \\
Conductivity & $\mathrm{mmhos}^{-1}$ & 1.8 \\
Nitrate & $\mathrm{mgL}^{-1}$ & 98.4 \\
Calcium & $\mathrm{mgkg}^{-1}$ & 78.09 \\
Potassium & $\mathrm{mgkg}^{-1}$ & 162.78 \\
Magnesium & $\mathrm{mgkg}^{-1}$ & 14.96 \\
Phosphorus & $\mathrm{mgkg}^{-1}$ & 2.00 \\
Boron & $\mathrm{mgkg}^{-1}$ & 0.62 \\
Copper & $\mathrm{mgkg}^{-1}$ & Not detected \\
Iron & $\mathrm{mgkg}^{-1}$ & 0.10 \\
Manganese & $\mathrm{mgkg}^{-1}$ & 0.15 \\
Zinc & $\mathrm{mgkg}^{-1}$ & Not detected \\
\hline
\end{tabular}


Table A3. Effect of different rates of putrescine on 3.5\% municipal solid waste compost tea turbidity, pH, salinity, electrical conductivity (EC) and total dissolved solids (TDS) after 48 hrs of mixing under room temperature and relative humidity conditions

\begin{tabular}{llllll}
\hline Rates $\left(\mathrm{mgL}^{-1}\right)$ & Turbidity $\left(\mathrm{NTU}^{*}\right)$ & $\mathrm{pH}$ & Salinity $\left(\mathrm{mgL}^{-1}\right)$ & $\mathrm{EC}\left(\mathrm{mgL}^{-1}\right)$ & $\mathrm{TDS}_{\left(\mathrm{mLL}^{-1}\right)}$ \\
\hline 0 (compost tea alone) & $34.20 \mathrm{a}$ & $6.73 \mathrm{a}$ & $126.63 \mathrm{a}$ & $256.33 \mathrm{a}$ & $202.44 \mathrm{a}$ \\
10 & $24.11 \mathrm{~b}$ & $6.69 \mathrm{a}$ & $128.63 \mathrm{a}$ & $262.72 \mathrm{a}$ & $204.21 \mathrm{a}$ \\
15 & $22.68 \mathrm{~b}$ & $6.63 \mathrm{a}$ & $130.41 \mathrm{a}$ & $266.27 \mathrm{a}$ & $206.48 \mathrm{a}$ \\
20 & $29.03 \mathrm{a}$ & $6.61 \mathrm{a}$ & $133.53 \mathrm{a}$ & $264.23 \mathrm{a}$ & $208.80 \mathrm{a}$ \\
25 & $30.9 \mathrm{a}$ & $6.54 \mathrm{a}$ & $134.80 \mathrm{a}$ & $262.25 \mathrm{a}$ & $206.31 \mathrm{a}$ \\
30 & $34.72 \mathrm{a}$ & $6.62 \mathrm{a}$ & $137.35 \mathrm{a}$ & $266.88 \mathrm{a}$ & $204.37 \mathrm{a}$ \\
P level & 0.03 & NS & NS & NS & NS \\
\hline
\end{tabular}

*NTU, Nephelometric Turbidity Unit; differences in means is denoted by differences in alphabetical letters within columns by Fisher's least significant difference at $\alpha=0.05$; NS, non-significance at $\mathrm{P}>0.05$.

\section{Copyrights}

Copyright for this article is retained by the author(s), with first publication rights granted to the journal.

This is an open-access article distributed under the terms and conditions of the Creative Commons Attribution license (http://creativecommons.org/licenses/by/3.0/). 